\title{
Histocompatibility antigens in multiple sclerosis patients participating in a multicentre trial of azathioprine
}

\author{
British \& Dutch Multiple Sclerosis Azathioprine Trial Group
}

SUMMARY The human leucocyte antigen (HLA) types of 283 patients with multiple sclerosis participating in a trial of azathioprine treatment were studied. The prevalence of HLA types was compared with those of over 3,300 controls from tissue typing centres in the UK. The prevalence of HLA A3 (38.5\% cp 26.1\%), HLA B7 (44.9\% cp 27.3\%) and HLA DR2 (58.3\% cp 30.6\%) was increased in the multiple sclerosis patients compared with the controls. Age at onset, disease status (relapsing-remitting or currently progressive) and disease severity did not show an association with any particular HLA type.

It is now well established that patients of northern European origin with multiple sclerosis show increased frequencies of certain histocompatibility antigen types, of which the association with HLADR2 has been the most significant. ${ }^{1}$ This finding is generally thought to indicate a genetic influence on susceptibility to the disease at or near the DR locus on the 6th chromosome. Previous studies have reached conflicting conclusions concerning whether particular HLA types influence clinical course and disease progression. ${ }^{2-4}$

In our current randomised double-masked multicentre trial of azathioprine we have studied the HLA types of 283 patients from the United Kingdom because they might be of value in predicting the efficacy of various therapeutic treatments. ${ }^{5}$ In this large series we have been able to look for the relationship between HLA types, clinical course and severity of the disease.

\section{Patients and methods}

Three hundred patients, from 18 neurological centres in the United Kingdom, were recruited into the trial (see table 1). An additional 54 patients recruited in Holland have not been tissue-typed. Patients were selected on the basis of age (between 15 and 50 years), and diagnostic classification ${ }^{6}$ (clinically definite, laboratory supported definite or

\footnotetext{
Address for reprint requests: British \& Dutch Multiple Sclerosis Azathioprine Trial Office, Department of Neurology, Guy's Hospital, London SE1 9RT, UK

Received 27 October 1987.

Accepted 9 November 1987
}

currently progressive multiple sclerosis). Entry was limited to those with a Kurtzke disability score ${ }^{7}$ of up to 6 (that is, requiring one but not two sticks to walk $50 \mathrm{~m}$ ). All the patients were Caucasoid and most were white Europeans but ${ }_{\mathbb{\Phi}}$ one, like her parents, was from the Seychelle Islands. Most $\bigcirc$ of the patients' parents were born in the UK, a few in Europe, one in Canada, and three patients had one parent born in India. Notification data included age at onset, duration of disease and Kurtzke disability score.?

The following clinical categories were compared with the HLA data: age at onset (35 years and above or below 350 years), disease course (remittent or currently progressive) and disease severity. Remittent multiple sclerosis was defined as a course of disease in which there were distinct attacks with stable phases between relapses. Relapses and remissions were defined by the Poser criteria. ${ }^{6}$ Progressive multiple sclerosis consisted of progressive evolution of disease from onset or a progressive phase following initial

Table 1 Completed tissue types according to region

\begin{tabular}{|c|c|c|}
\hline Region & $\begin{array}{l}\text { No. } \\
\text { typed }\end{array}$ & $\begin{array}{l}\text { Percentage } \\
\text { of the total } \\
\text { sample }\end{array}$ \\
\hline $\begin{array}{l}\text { Scotland } \\
\text { (Aberdeen, Dundee) }\end{array}$ & $73 / 75$ & $25 \cdot 6$ \\
\hline $\begin{array}{l}\text { Northern England } \\
\text { (Newcastle, Wakefield, Liverpool, } \\
\text { Manchester) }\end{array}$ & $77 / 80$ & $27 \cdot 2$ \\
\hline $\begin{array}{l}\text { Midlands \& East Anglia } \\
\text { (Coventry, Birmingham, Norwich, } \\
\text { Ipswich, Cambridge) }\end{array}$ & $23 / 29$ & $8 \cdot 1$ \\
\hline $\begin{array}{l}\text { Wales } \\
\text { (Cardiff) }\end{array}$ & $17 / 17$ & 6.0 \\
\hline $\begin{array}{l}\text { London \& Home Counties } \\
\text { (National, Guy's, Brook General } \\
\text { Hospitals, Oxford) }\end{array}$ & $60 / 63$ & $21 \cdot 2$ \\
\hline $\begin{array}{l}\text { Southern England } \\
\text { (Southampton, Brighton) }\end{array}$ & $33 / 33$ & $11 \cdot 7$ \\
\hline Total & $283 / 300$ & $94 \cdot 3$ \\
\hline
\end{tabular}


remissions. Disease severity was classified into benign and severe categories. Patients assigned to have benign disease had a score of 3.5 or less on the Kurtzke scale after 10 years from the onset of their initial symptoms. Patients assigned to have severe disease had a Kurtzke score of 5 or more within 5 years of their first symptoms.

Tissue typing was done locally where possible at recognised laboratories using well validated antisera in a standard microlymphocytotoxicity test. $^{89}$ Unfractionated or $T$ lymphocytes were used for the assignment of $A, B$ and $C$ antigens and enriched populations of $B$ lymphocytes for the determination of DR antigens. Positive typing for a given antigen specificity was based on concordant reactions with two or more antisera. When the results were equivocal the test was repeated with a fresh blood sample. Table 1 shows the proportion of patients from each centre satisfactorily typed. Because of regional variations in HLA antigen frequencies (Hall $P$, personal communication) control data from more than 3,000 individuals from 19 major UK tissue typing centres were compared with antigen frequencies in the overall patient group.

\section{Results}

\section{Whole group}

Two hundred and eighty three (94\%) of the original 300 patients were satisfactorily typed. In three patients the types were incomplete, with either A, B, $C$ or DR assignments missing, and were therefore excluded from the analysis. Six patients had died before being typed and in the remaining eight patients the tissue types were not available for analysis owing to technical reasons or patient non-compliance.

The distribution of HLA antigens overall revealed a preponderance of HLA-B7 and HLA-DR2 in patients with multiple sclerosis (table 2). These anti-

Table 2 Frequencies of selected HLA antigens in the overall multiple sclerosis and control groups

\begin{tabular}{|c|c|c|c|c|c|}
\hline & & $\begin{array}{l}\text { Multiple } \\
\text { sclerosis } \\
n=283 \\
\%\end{array}$ & $\begin{array}{l}\text { Controls } \\
n=3601 \\
\%\end{array}$ & $\chi^{2}$ & p correct ${ }^{*}$ \\
\hline \multirow[t]{2}{*}{ HLA } & $\begin{array}{l}\text { A1 } \\
\text { A2 } \\
\text { A3 }\end{array}$ & $\begin{array}{l}41 \cdot 6 \\
36 \cdot 0 \\
38 \cdot 5\end{array}$ & $\begin{array}{l}35 \cdot 2 \\
49 \cdot 0 \\
26 \cdot 1\end{array}$ & $\begin{array}{r}3 \cdot 10 \\
17 \cdot 17 \\
19 \cdot 88\end{array}$ & $\begin{array}{l}\text { NS } \\
6 \cdot 0^{-3} \\
5 \cdot 0^{-3}\end{array}$ \\
\hline & & & $\begin{array}{l}n=3600 \\
\%\end{array}$ & & \\
\hline \multirow[t]{2}{*}{$\begin{array}{l}\text { HLA } \\
\text { B12 }\end{array}$} & $\begin{array}{l}\text { B7 } \\
\text { B8 } \\
(44)\end{array}$ & $\begin{array}{l}44 \cdot 9 \\
28 \cdot 6 \\
18 \cdot 0\end{array}$ & $\begin{array}{l}27 \cdot 3 \\
28 \cdot 8 \\
20 \cdot 2\end{array}$ & $\begin{array}{r}38.97 \\
0.02 \\
0.63\end{array}$ & $\begin{array}{l}1 \cdot 2^{-4} \\
\mathrm{NS} \\
\mathrm{NS}\end{array}$ \\
\hline & & & $\begin{array}{l}n=3306 \\
\%\end{array}$ & & \\
\hline HLA & $\begin{array}{l}\text { DR1 } \\
\text { DR2 } \\
\text { DR3 } \\
\text { DR4 } \\
\text { DR5 } \\
\text { DRw6 } \\
\text { DR7 }\end{array}$ & $\begin{array}{r}12 \cdot 4 \\
58 \cdot 3 \\
30 \cdot 0 \\
23 \cdot 0 \\
8 \cdot 8 \\
12 \cdot 4 \\
19 \cdot 8\end{array}$ & $\begin{array}{l}18 \cdot 5 \\
30 \cdot 6 \\
29 \cdot 1 \\
34 \cdot 4 \\
12 \cdot 8 \\
19 \cdot 4 \\
26 \cdot 6\end{array}$ & $\begin{array}{r}6.25 \\
89.46 \\
<0.01 \\
13.82 \\
3.39 \\
8.01 \\
5.56\end{array}$ & $\begin{array}{l}\text { NS } \\
1.0^{-9} \\
\text { NS } \\
3 \cdot 0^{-2} \\
\text { NS } \\
\text { NS } \\
\text { NS }\end{array}$ \\
\hline HLA & DR2-DR3 & $8 \cdot 5$ & 8.9 & 0.02 & NS \\
\hline
\end{tabular}

${ }^{*} \mathrm{p}$ corrected for number of antigens tested ( 58 antigens). gens were significantly increased compared with the normal population, while the frequency of HLA-A3 was only slightly higher in patients. HLA-A2, was significantly under represented in the patient group. Positive associations with HLA-DR3 or the combination HLA DR2-DR3 were not evident in patient and control groups as a whole, but when HLA-DR2 positive individuals were excluded from the analysis HLA-DR3 was significantly elevated in patients compared with normal individuals (HLA-DR3: $51.7 \%$ and $29.2 \%$ respectively of HLA-DR2 negative patients and controls $\chi^{2}=25.8, \mathrm{p}<0.0005$ ).

\section{Early and late disease onset subgroups}

Subgrouping into two groups of patients by age at onset, revealed no significant differences in the distribution of HLA antigens. Thus the 218 patients with age at onset before 35 years had HLA-A3, B7, and DR2 frequencies of $39 \%, 44 \%$ and $60 \%$ respectively. The corresponding frequencies for the 65 patients with onset after 35 years were $39 \%, 46 \%$ and $54 \%$ respectively.

\section{Subgroups divided according to disease course}

One hundred and ninety six patients had remittent disease compared with 87 patients in whom the disease was currently progressive and the distribution of HLA types was similar (table 3). Because initial qualification for the trial required patients to be ambulant, relatively few patients fulfilled our criteria for severe multiple sclerosis. Nevertheless, 23 patients were considered to have severe disease and 50 patients had benign multiple sclerosis. When the histocompatibility types were compared between these clinical subgroups no significant differences were noted (table 4).

\section{Discussion}

Our data drawn from patients throughout the UK confirm the strong association between multiple sclerosis and HLA-DR2, and lesser associations with HLA-B7 and HLA-A3. The previously noted ${ }^{11}$ increase in HLA-DR3 was also found in our patient

Table $3 H L A$ typing according to clinical course

\begin{tabular}{|c|c|c|c|c|c|}
\hline & & $\begin{array}{l}\begin{array}{l}\text { Remittent } \\
\text { multiple }\end{array} \\
\text { sclerosis } \\
n=196 \\
\%\end{array}$ & $\begin{array}{l}\text { Progressive } \\
\text { multiple } \\
\text { sclerosis } \\
n=87 \\
\%\end{array}$ & $\chi^{2}$ & $p$ \\
\hline $\begin{array}{l}\text { HLA } \\
\text { HLA } \\
\text { HLA }\end{array}$ & $\begin{array}{l}\text { A1 } \\
\text { A3 } \\
\text { B7 } \\
\text { B8 } \\
\text { DR2 } \\
\text { DR3 } \\
\text { DR2-DR3 }\end{array}$ & $\begin{array}{r}41 \cdot 3 \\
37 \cdot 2 \\
42 \cdot 9 \\
30 \cdot 1 \\
56 \cdot 6 \\
30 \cdot 1 \\
7 \cdot 7\end{array}$ & $\begin{array}{l}39 \cdot 1 \\
41 \cdot 4 \\
49 \cdot 4 \\
25 \cdot 3 \\
61 \cdot 1 \\
26 \cdot 4 \\
10 \cdot 3\end{array}$ & $\begin{array}{l}0.04 \\
0.28 \\
0.80 \\
0.47 \\
0.53 \\
0.23 \\
0.27\end{array}$ & $\begin{array}{l}\text { NS } \\
\text { NS } \\
\text { NS } \\
\text { NS } \\
\text { NS } \\
\text { NS } \\
\text { NS }\end{array}$ \\
\hline
\end{tabular}


Table 4 HLA typing according to disease severity

\begin{tabular}{|c|c|c|c|c|c|}
\hline & & $\begin{array}{l}\text { Benign } \\
\text { multiple } \\
\text { sclerosis* } \\
n=50 \\
\%\end{array}$ & $\begin{array}{l}\text { Severe } \\
\text { multiple } \\
\text { sclerosis* } \\
n=23 \\
\%\end{array}$ & $\chi^{2}$ & $p$ \\
\hline HLA & $\begin{array}{l}\text { A1 } \\
\text { A3 }\end{array}$ & $\begin{array}{l}44 \cdot 0 \\
44 \cdot 0\end{array}$ & $\begin{array}{l}34 \cdot 8 \\
39 \cdot 1\end{array}$ & $\begin{array}{l}0.24 \\
0.02\end{array}$ & $\begin{array}{l}\text { NS } \\
\text { NS }\end{array}$ \\
\hline HLA & B7 & 38.0 & $52 \cdot 2$ & 0.78 & NS \\
\hline & B8 & $32 \cdot 0$ & $26 \cdot 1$ & 0.06 & NS \\
\hline HLA & DR2 & 52.0 & 60.9 & 0.21 & NS \\
\hline & $\begin{array}{l}\text { DR3 } \\
\text { DR2-DR 3 }\end{array}$ & $\begin{array}{l}40.0 \\
10.0\end{array}$ & $\begin{array}{l}34.8 \\
13.0\end{array}$ & $\begin{array}{r}0.28 \\
<0.01\end{array}$ & $\begin{array}{l}\text { NS } \\
\text { NS }\end{array}$ \\
\hline HLA & B7-DR3 & 34.0 & $34 \cdot 8$ & 0.04 & NS \\
\hline & B8-DR3 & $30 \cdot 0$ & $26 \cdot 1$ & $<0.01$ & NS \\
\hline
\end{tabular}

*See patients and methods.

group when the confounding effect of the stronger HLA-DR2 association was excluded from the analysis. There is evidence from previous studies that the higher prevalences of multiple sclerosis noted with increasing latitude in this country are matched by a corresponding increase in the frequency of HLA-DR2 in the normal population whereas the overall proportion of affected individuals who carry this antigen remains constant. ${ }^{1112}$ This would account for the comparatively high frequency of HLA-DR2 noted in our pooled British control population $(30 \%)$ which has effectively reduced the overall significance of DR2 in the patient group. Nevertheless the risk of developing multiple sclerosis for HLA-DR2 carriers in this study is $3 \cdot 16$ times higher than for HLA-DR2 negative individuals and 3.17 times higher for those carrying HLA-B7. This genetically determined increased risk has best been explained by assuming the existence of a multiple sclerosis susceptibility gene which occurs in linkage with the HLA-DR2 locus on the 6th chromosome. The high proportion of supposedly genetically susceptible, yet unaffected, HLA-DR2 positive individuals seen in northern parts of Great Britain therefore offers some explanation for the high prevalences of multiple sclerosis noted in these regions but does not rule out the possible influence of HLA-DR3 and other genetic or environmental factors.

Both Jersild et al. ${ }^{2}$ and Stendahl-Brodin et al. $^{3}$ presented data indicating that patients with severe multiple sclerosis had a high frequency of HLA-Dw2 (broadly equivalent to HLA-DR2), while those with benign disease had a low frequency of this antigen. In support of these findings Raun et al. ${ }^{4}$ found a positive correlation between the presence of HLA-Dw2 and rapidly progressive disease thereby implicating an association between HLA type and the severity of multiple sclerosis. This proposal has not been confirmed in more recent studies, ${ }^{101314}$ and analysis of the clinical course and progression of disease over time in the present series has also failed to support this suggestion. We were unable to confirm the suggestion of Madigand et al..$^{10}$ who proposed the presence of two distinct clinical subgroups of patients differentiated by their HLA type (HLA-B7-DR2 characterising benign, remittent disease and HLA-B8-DR3 severe, progressive disease). In interpreting our results it must be remembered that patients with the most severe forms of disease (Kurtzke score $>6$ ) were excluded from trial entry. Finally, unlike Dejeagher $e t$ $a l .{ }^{15}$ we found no evidence that the age of onset of disease differed between HLA-DR2 positive and DR2 negative patients. Our data, therefore, provide no evidence for HLA-controlled clinical heterogeneity within multiple sclerosis and the presence of HLA-DR2 did not appear to indicate an unfavourable prognosis.

A large number of associations between multiple sclerosis and the HLA system have been proposed mostly on the basis of small studies. The results of our larger series of patients, while confirming the overall association between HLA-DR2 and disease susceptibility, have provided no evidence for the direct influence of HLA genes on clinical parameters within the disease. Several investigators have suggested retrospectively that the efficacy of certain immunosuppressive regimes in multiple sclerosis is dependent upon the individuals HLA status. ${ }^{1016}$ It remains to be determined in this prospective study whether a response to azathioprine treatment is influenced by his or her HLA type.

This report was prepared by Dr D A Francis. The following provided the tissue types: Dr R M R Barnes, Royal Liverpool Hospital; Prof J R Batchelor, N Davey BSc, Royal Postgraduate Medical School; Dr Ewa M Brookes, A O'Sullivan, East of Scotland Blood Transfusion Service; Dr C Darke, Prince of Wales Hospital, Rhydlafar, Cardiff; Dr P A Dyer, St Mary's Hospital, Manchester; Dr U Jayaswal, Wessex Regional Transfusion Centre; Dr V C Joysey, Addenbrooke's Hospital; PA Learoyd, Dr S M Rajah, Yorkshire Regional Transfusion Laboratory; Miss A Stratton, Northern Regional Transfusion Centre, Newcastle-upon-Tyne; C Taylor, Dr A Ting, John Radcliffe Hospital; R Vaughan MSc, Dr K Welsh, Guy's Hospital. We thank Dr P Hall for making available this analysis of HLA data in the UK population.

The participating centres were the neurology departments in the following hospitals: Aberdeen Royal Infirmary; Queen Elizabeth Hospital, Birmingham; Newmarket General Hospital; University Hospital of Wales; Walsgrave Hospital, Coventry; Dundee Royal Infirmary; Royal East Sussex Hospital, Hastings; Ipswich Hospital; Walton Hospital, Liverpool; Pembury Hospital, Pembury; West Hill Hospital, Dartford; The Radcliffe 
Infirmary, Oxford; Southampton General Hospital; Pinderfields General Hospital, Wakefield; Addenbrooke's Hospital, Cambridge; Brook General Hospital, Guy's Hospital, National Hospital for Nervous Diseases, London; Manchester Royal Infirmary; Royal Victoria Infirmary, Newcastleupon-Tyne; Norfolk \& Norwich Hospital; Academisch Ziekenhuis, Groningen, The Netherlands.

A list of participants in this trial can be obtained from the British \& Dutch Multiple Sclerosis Azathioprine Trial Office, Department of Neurology, United Medical and Dental Schools of Guy's and St Thomas's Hospitals, Guy's Hospital, London SE1 9RT where correspondence should be addressed. The trial was supported by the Medical Research Council and the Wellcome Foundation Ltd.

\section{References}

1 McDonald WI. Multiple sclerosis: epidemiological and HLA associations. In: Scheinberg L, Raine CS, eds. Multiple Sclerosis: Experimental and clinical aspects. New York: New York Academy of Sciences, 1984:109-17.

2 Jersild C, Fog T, Hansen GS, Thomsen M, Svejgaard A, Dupont B. Histocompatibility determinants in multiple sclerosis with special reference to clinical course. Lancet 1973;ii:1221-4.

3 Stendahl-Brodin L, Link H, Moller E, Norrby E. Genetic basis of multiple sclerosis: HLA antigens, disease progression and oligoclonal IgG in CSF. Acta Neurol Scand 1979;59:297-308.

4 Raun NE, Fog T, Heltberg A, Platz P. Correlation of the course of MS and histocompatibility antigens. In: Bauer HJ, Poser S, Ritter G, eds. Progress in Multiple Sclerosis Research. Berlin, Heidelberg, New York: Springer-Verlag, 1980:456-9.

5 Mertin J, Rudge P, Kremer M, et al. Double-blind controlled trial of immunosuppression in the treatment of multiple sclerosis. Final report. Lancet 1982;ii:351-4.

6 Poser CM, Paty DW, Scheinberg L, et al. New diagnostic criteria for multiple sclerosis: guidelines for research protocols. Ann Neurol 1983;13:227-31.

7 Kurtzke JF. Further notes on disability evaluation in multiple sclerosis with scale modifications. Neurology 1965;15:654-61.

8 Terasaki PI, McClelland JD. Microdroplet assay of human serum cytotoxins. Nature 1964;204:998.

9 Bodmer JG, Pickbourne P, Richards S. Ia serology. In: Bodmer WF, Batchelor JR, Bodmer JG, Festenstein H, Morris PJ, eds. Histocompatibility Testing 1977; Copenhagen: Munksgaard: 35-84.

10 Madigand M, Oger JJ-F, Fauchet R, Sabouraud O, Genetet B. HLA profiles in multiple sclerosis suggest two forms of disease and the existence of protective haplotypes. J Neurol Sci 1982;53:519-29.

11 Francis DA, Batchelor JR, McDonald WI, Hern JEC, Downie AW. Multiple sclerosis and HLA-DQwl. Lancet 1986;i:211.

12 Swingler RJ, Compston DAS. Distribution of MS in UK. J Neurol Neurosurg Psychiatry 1986;49:1115-24.

13 Poser S, Ritter G, Bauer HJ, Gross-Wilde H, Kumert EK, Raun NE. HLA antigens and the prognosis of multiple sclerosis. J Neurol 1981;225:219-21.

14 Collins RC, Espinoza LR, Plank CR, Ebers GC, Rosenberg RA, Zabriskie JB. A double-blind trial of transfer factor vs placebo in multiple sclerosis patients. Clin Exp Immunol 1978;33:1-11.

15 Dejaegher L, de Bruyere M, Ketelaer P, Carton H. HLA antigens and progression of multiple sclerosis. Part II. J Neurol 1983;229:167-74.

16 Hommes OR, Lamers KJB, Reekers P. Prognostic factors in intensive immunosuppressive treatment of chronic progressive multiple sclerosis. In: Bauer $\mathrm{H}$, et al. eds. Progress in MS research. Berlin, Heidelberg, New York: Springer,1980;396-400. 